FULL RESEARCH ARTICLE

\title{
Ecological variation among island foxes relative to reproductive events
}

ROBYN M. POWERS ${ }^{1}$, BRIAN L. CYPHER ${ }^{2 *}$, KATHERINE RALLS $^{3}$, JAN A. RANDALL ${ }^{4}$, AND ERICA C. KELLY ${ }^{2}$

${ }^{1}$ Terra Verde Environmental Consulting, 3765 S. Higuera Street, San Luis Obispo, CA 93401, USA

${ }^{2}$ California State University-Stanislaus, Endangered Species Recovery Program, One University Circle, Turlock, CA 95382, USA

${ }^{3}$ Center for Conservation Genomics, Smithsonian Conservation Biology Institute, $\mathrm{Na}$ tional Zoo, Washington, DC 20008 USA

${ }^{4}$ Department of Biology, San Francisco State University, 1600 Holloway Avenue, San Francisco, CA 49123

* Corresponding Author: bcypher@esrp.csustan.edu

Ecological attributes of a species can vary as resource requirements and social interactions change in response to the annual reproductive cycle. We examined variation in home range size, home range overlap, activity (2005-2006), and food item selection (2006-2007) of island foxes (Urocyon littoralis) on San Nicolas Island relative to reproduction-related events. Home ranges, particularly for males, were larger during the mating period compared with the post-mating, pup-rearing, and non-reproduction periods. Home range overlap with non-mate neighbors also increased during the mating period. The greater home range size and overlap during the mating season is consistent with foxes, particularly males, traveling into the ranges of neighboring pairs in an attempt to secure extra-pair copulations. Daily activity patterns did not vary among the reproductive periods. Use of vertebrate prey items increased during the period when adults would have been provisioning weaning young. These items (e.g., mice, birds, lizards) are protein-rich and easier to transport compared with smaller items (e.g., fruits, snails, insects) that also are commonly consumed by island foxes. Variation in ecological attributes among island foxes across the different seasons defined by reproductive events likely represents efforts to maximize mating opportunities, particularly among adult males, and to secure optimal resources for provisioning growing young. These patterns are consistent with those observed among other small canid species. 
Key words: activity, Channel Islands, food habits, home range, island fox, reproductive cycle, San Nicolas Island, Urocyon littoralis

Ecological attributes of a species can vary temporally as resource requirements and social interactions change in response to the annual reproductive cycle. This is particularly pronounced in mammals, where finding and defending mates in addition to increased energetic demands associated with bearing and rearing young can influence use of space and resources (Gittleman and Thompson 1988; Oftedal and Gittleman 1989). However, the capacity for species to alter ecological patterns may be reduced in situations where space or resources are limited, such as in insular habitats (Whittaker and Fernández-Palacios 2007).

We examined variation in ecological attributes of San Nicolas island foxes (Urocyon littoralis dickeyi) relative to reproduction-related events. Island foxes are dwarf descendants of the mainland gray fox ( $U$. cinereoargenteus) and earlier evidence based on genetics suggested that the two species diverged about 16,000 to 20,000 years ago (Gilbert et al. 1990; Wayne et al. 1991; Goldstein et al. 1999). However, more recent evidence suggests that mainland gray foxes initially colonized the northern islands about 9,200-7,100 years ago, probably by rafting or human introduction, followed by human translocation from the northern to the southern islands, and these foxes then underwent rapid evolution and speciation resulting in the six subspecies recognized currently (Rick et al. 2009; Hofman et al. 2015, 2016). These six subspecies occur on the six largest Channel Islands. All six are listed as California Threatened (CDFG 1987) because of small population sizes, and one population (Santa Catalina Island) is also listed as Threatened by the U.S. Fish and Wildlife Service (USFWS 2016) because of the high risk of disease introduction (Coonan et al. 2013). Enhanced understanding of the ecology and biology of island foxes could facilitate conservation efforts.

Island fox densities typically are higher than those of mainland gray foxes due to a lack of predators and severe limits on dispersal associated with the limited space of an island (Roemer et al. 2001). Furthermore, this insular situation results in limited resources compared to mainland areas with similar habitat conditions. Thus, these pressures might restrict or even suppress changes in ecological attributes associated with reproductive activities. San Nicolas Island is the second smallest of the islands that support a fox population, but population density commonly is higher than that on any of the other islands with foxes (Coonan et al. 2010). This high density further enhances resource and social pressures on foxes. Our objectives were to determine whether home range size, home range overlap, activity, and food item selection of island foxes varied with reproductive cycle chronology and the reproductive status of individual foxes. We compared our results to those available from other islands as well as to those for other small canids in non-insular situations.

\section{METHODS}

\section{Study Area}

Our study was conducted on San Nicolas Island (SNI), California (33 $13^{\circ}$ '23'N, $\left.119^{\circ} 27^{\prime} 29^{\prime \prime} \mathrm{W}\right)$. SNI comprises $58 \mathrm{~km}^{2}$ and is located in the Pacific Ocean ca. $100 \mathrm{~km}$ off the coast of southern California (Fig. 1). The island largely consists of an elevated sandstone plateau with steep, eroded slopes leading to the shoreline (Schoenherr et al. 1999). 


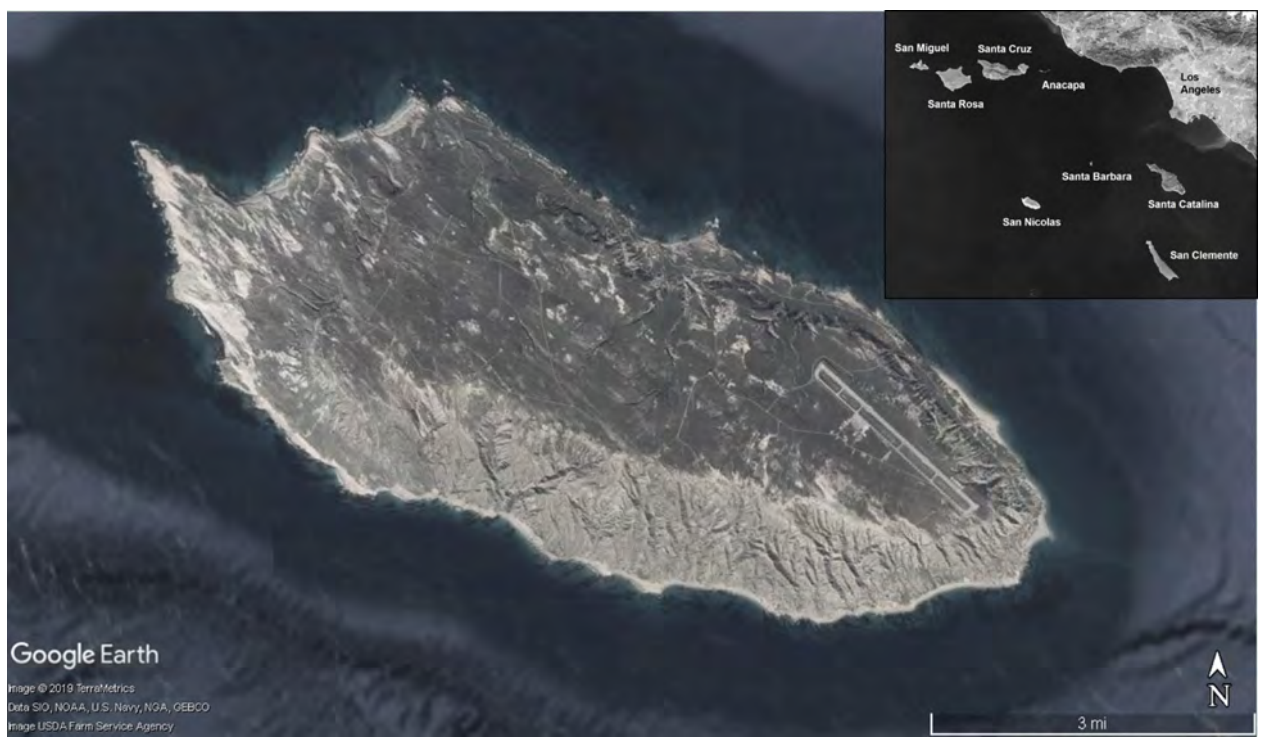

Figure 1. San Nicolas Island and its location relative to the other Channel Islands off the coast of southern California, USA.

Maximum elevation is $277 \mathrm{~m}$. Climate on the island is relatively arid with annual precipitation averaging $200 \mathrm{~mm}$. Much of the island is sparsely vegetated from a combination of aridity and continued effects of past overgrazing by domestic sheep (sheep were present from the 1800 s to the 1940s; U.S. Navy 2005). Primary vegetation communities are mixed coastal scrub and grasslands dominated by non-native Eurasian annual species. Non-native grassland and barren or sparsely vegetated areas (resulting from severe erosion) comprise approximately $36 \%$ of the land cover on the island; coastal scrub covers an additional $42 \%$ but much of this community is degraded by encroachment of non-native species (Junak 2008). Dominant plants include coastal goldenbush (Isocoma menziesii), giant coreopsis (Leptosyne gigantea), bush lupine (Lupinus albifrons), coyote brush (Baccharis pilularis), and non-native grasses such as slender wild oats (Avena barbata), ripgut brome (Bromus diandrus), and foxtail barley (Hordeum murinum).

SNI is managed by the U.S. Navy which conducts missile testing and other military support activities (USFWS 2009). The island is closed to the public; access is limited to Navy personnel, federal civil servants, and contractors. Large portions of the island are regularly closed for military operations and to protect sensitive environmental and cultural sites. Consequently, we collected data primarily in the eastern third of the island where restrictions were less frequent.

\section{Live-trapping and Study Animals}

Island foxes were trapped and handled following protocols approved by the Institutional Animal Care and Use Committee at San Francisco State University. We trapped and radio-collared 18 island foxes: six adult females, eight adult males, and four juvenile males. We used single-door, wire-mesh box traps with dimensions of 66 × 23 × $23 \mathrm{~cm}$ (Tomahawk 
Live Trap Co., Tomahawk, WI). We attempted to capture all foxes present in our study area. Traps were placed along roads, fox trails, and transects traversing the plateau. A rubber hose was attached to the inside of each trap as a chew bar to prevent potential injuries to the teeth of foxes caused by biting the trap. We covered the top and sides of all traps with burlap and heavy vegetation for protection from sun, wind, and dew exposure, and dry grass was placed inside the traps for bedding. We baited traps daily with wet cat food, opened at sunset, checked at sunrise, and closed during the day. Trapping began on 6 November 2005 and ended on 7 January 2006 when only recaptures were caught for several consecutive days.

For captured foxes, we observed and recorded the general health, mass, age, sex, and reproductive condition. Age was determined by an age-class system based on molar wear that was originally used for mainland gray foxes (Wood 1958), and adapted for island foxes. We attached a radiocollar (Model 1930 with mortality sensor by Advanced Telemetry Systems, Isanti, MN) to each fox, and the fox was immediately released at the capture site.

\section{Tracking}

We tracked collared foxes from 10 December 2005-1 April 2006 (reproduction) and from 15 June-12 July 2006 (non-reproduction). We located signals from collared foxes with a hand-held H type antenna (Telonics, Inc., Mesa, AZ) and a R-1000 telemetry receiver (Communications Specialists, Inc., Orange, CA). We recorded the UTM coordinates for each monitoring location, and then the compass bearing for the direction of the strongest signal from each fox being monitored. We then moved rapidly to a second monitoring location and repeated the process. Each night, we monitored one or two of the collared females (focal females) and any other foxes in their vicinity. Monitoring began at sunset and we attempted to collect locations on each monitored fox at about 20-min intervals for a period of approximately $2 \mathrm{~h}$ per focal female. Females were designated as focal at intervals of $\geq$ 3 nights. We also collected one afternoon location for each fox at least twice per week.

Recommendations for achieving independence of locations require that the animal can theoretically traverse its home range in the time between recorded locations (Swihart and Slade 1985). Island fox home ranges are relatively small (see Results), and each fox in our study demonstrated an ability to move the length of its range between telemetry fixes. Also, we used the minimum convex polygon (MCP) method to estimate home ranges, and nonstatistical home range methods like the MCP are less sensitive to non-independence among locations compared with statistical home range methods (e.g., kernel density), provided the temporal distribution and sample size of locations are sufficient to capture full home range use by animals (Swihart and Slade 1985).

\section{Activity}

We recorded activity patterns of collared island foxes during four time periods: sunrise, afternoon, sunset, and night. We defined sunrise as $1.5 \mathrm{~h}$ before to $1.5 \mathrm{~h}$ after sunrise, and sunset similarly was defined as $1.5 \mathrm{~h}$ before to $1.5 \mathrm{~h}$ after sunset. Fluctuations in signal strength indicated when a fox was active. Over the course of a 2-min time period, if the signal strength was consistent, we recorded the fox as "inactive", and if the signal strength fluctuated the fox was recorded as "active." Activity was recorded for each collared fox a minimum of twice per week during each of the four time periods. For each fox and reproductive period, we determined the proportion of active detections. 


\section{Food Item Selection}

We did not collect island fox scats during the telemetry field work, but we did collect scats during comparable months the next year. We collected scats from December 2006 to July 2007 , mostly along roads where foxes commonly scent mark. Scat samples were collected into paper bags and allowed to air-dry. We then carefully separated the contents of each scat, and identified individual food items within the samples to the lowest taxonomic level possible. We identified mammalian remains based on bone and dental fragments and guard hair characteristics. Bird identification was based on feather and foot characteristics, and we identified insects from exoskeleton characteristics. Fruits were identified based on seed and exocarp characteristics. Items were identified using guides (e.g., Moore et al. 1974, Glass 1981, Roest 1986, Young and Young 1992) or by comparison with reference collections. We were primarily interested in the temporal pattern of use of vertebrates by the foxes as these are the items that are used to provision pups post-nursing.

\section{Data Analyses}

We defined three periods during island fox reproduction: mating, post-mating, and pup-rearing. Mating period data were gathered during 15 December-31 January. Island foxes have a gestation period of 50-53 days with parturition reported in late April or early May on Santa Cruz Island (Laughrin 1977). The mating period on San Miguel Island, another of the northern islands, is in February, also indicating that the peak of parturition would occur in April (Ralls et al. 2013). However, females in our study bore litters from early to mid-March, which indicates they were all pregnant in February and that the mating period occurs earlier on SNI, which is one of the southern islands. Therefore, we defined the post-mating period as 1-29 February and the pup-rearing period as 1 March-31 May, when parturition occurred and foxes nursed pups and subsequently provisioned them with solid food during weaning. For comparison, we also collected data during 15 June-12 July, defined as the non-reproduction period.

We used location data to analyze changes in home range size and overlap over the three reproductive periods and the non-reproductive period. We entered monitoring location coordinates and signal bearings into the program LOAS (Ecological Software Solutions, LLC, Hegymagas, Hungary) and used these data to calculate triangulated fox locations. These locations were then entered into the program BIOTAS (Ecological Software Solutions, LLC, Hegymagas, Hungary) to calculate home range size and overlap. We used the $95 \% \mathrm{MCP}$ method to delineate home ranges because it provided a better representation of home range configuration compared to the commonly used Kernel method. The Kernel method tended to artificially divide many fox home ranges into segments consisting of ridges or plateau areas because we had difficulty obtaining locations when foxes were in the intervening deep canyons. The MCP method better captured the actual extent of home ranges and is considered a more conservative estimate of home range size (Harris et al. 1990). The minimum number of locations used to calculate a home range was 20 , and the overall average was 47 locations per home range. Juveniles were excluded from home range analyses because of an insufficient number of locations. The mean number of locations used to estimate home ranges in each reproductive period was $49.4 \pm 3.6$ for females and $43.8 \pm 2.9$ for males. The $75 \%$ and $55 \%$ MCP ranges were calculated to identify areas of intense use, or "core areas". Because the island fox home ranges were relatively small, the $75 \% \mathrm{MCP}$ core areas and the $55 \%$ MCP core areas were similar and thus we used the former. 
To assess whether social interactions between foxes varied with reproductive period, we calculated home range overlaps. For a given fox, overlap was calculated as the proportion of total home range or core area that was overlapped by another monitored fox; thus, these data were not completely independent as data from a given were used in the calculations of two or more overlap estimates. For each fox, we calculated overlap for three types of dyads: male-female mates, most overlapping non-mate neighbor, and most overlapping same sex neighbor. We determined mates based on observations of males being present at the dens of a particular female during pup-rearing. For the other two dyads, we determined which neighboring fox of the opposite sex overlapped the most and which neighboring fox of the same sex overlapped the most with the subject fox. Overlaps were calculated for each fox for each reproductive period, and for both $95 \%$ and $75 \%$ MCP ranges.

We conducted statistical analyses using SYSTAT 10.0 (SPSS Inc., Chicago). We compared mean home range size between sexes and reproductive periods with a two-way repeated measures analysis of variance. We used multivariate analysis of variance to compare mean proportional overlap of $95 \%$ and $75 \%$ ranges between sexes, dyads, and reproductive periods and to compare mean proportional activity between sexes, reproductive period, and daily period. Prior to analysis, we transformed overlap and activity proportions using an arcsine transformation (Zar 1984). Results are reported using the multivariate Wilks' lambda and post-hoc paired $t$-tests with Bonferroni corrections when applicable. All results are presented as mean \pm SE. Use of vertebrate food items was qualitatively compared between reproductive periods.

\section{RESULTS}

\section{Home Range Size}

Mean home range sizes of reproductive adult males and females were similar $\left(F_{1,6}=\right.$ 5.36, $P=0.060$ ) although male ranges trended toward being larger than those of females during the mating period (Fig. 2). Home range size of reproductive foxes differed among reproductive periods $\left(F_{3,4}=13.48, P=0.015\right)$. During the mating period mean home range size for both sexes was $181.3 \pm 25.4$ ha and was significantly smaller in the post-mating $\left(t_{3,7}\right.$ $=4.33, P=0.021)$, pup-rearing $\left(t_{3,7}=4.71, P=0.013\right)$, and non-reproductive periods $\left(t_{3,7}=\right.$ $3.60, P=0.053)$ averaging $63.9 \pm 6.6 \mathrm{ha}, 61.6 \pm 7.2 \mathrm{ha}$, and $63.5 \pm 15.8 \mathrm{ha}$, respectively. The two non-reproductive females had very small home ranges throughout the study, especially in the post-mating ( $4.1 \pm 2.1$ ha) and pup-rearing (5.7 \pm 0.4 ha) periods (Fig. 2).

Home range overlap.-Overlap of $95 \%$ MCP ranges among foxes was extensive (47-100\%), even between non-mate neighbors. Consequently, there were no differences in amount of overlap between reproductive periods or fox dyads. However, the $75 \% \mathrm{MCP}$ area overlaps provided more insights. Mean overlap varied among reproductive periods $\left(F_{3,14}\right.$ $=3.55, P=0.042)$ and was significantly greater in the mating period than in the pupping period $\left(t_{3,10}=3.42, P=0.017\right)$ but similar among all other periods (Table 1$)$. Mean overlap varied among the three categories of fox dyads $\left(F_{2,16}=9.32, P=0.002\right)$. It was highest for mated pairs and similar between nearest non-mate neighbors and nearest same sex neighbors (Table 1). The amount of overlap in each dyad category varied with reproductive period $\left(F_{8,26}=2.80, P=0.022\right)$. Specifically, percentage overlap of mated pairs was larger than that of the nearest non-mate neighbor of opposite sexes and the nearest same sex neighbor in the post-mating $\left(F_{2,16}=4.61, P=0.026\right)$, pup-rearing $\left(F_{2,16}=13.81, P=0.001\right)$, and non- 


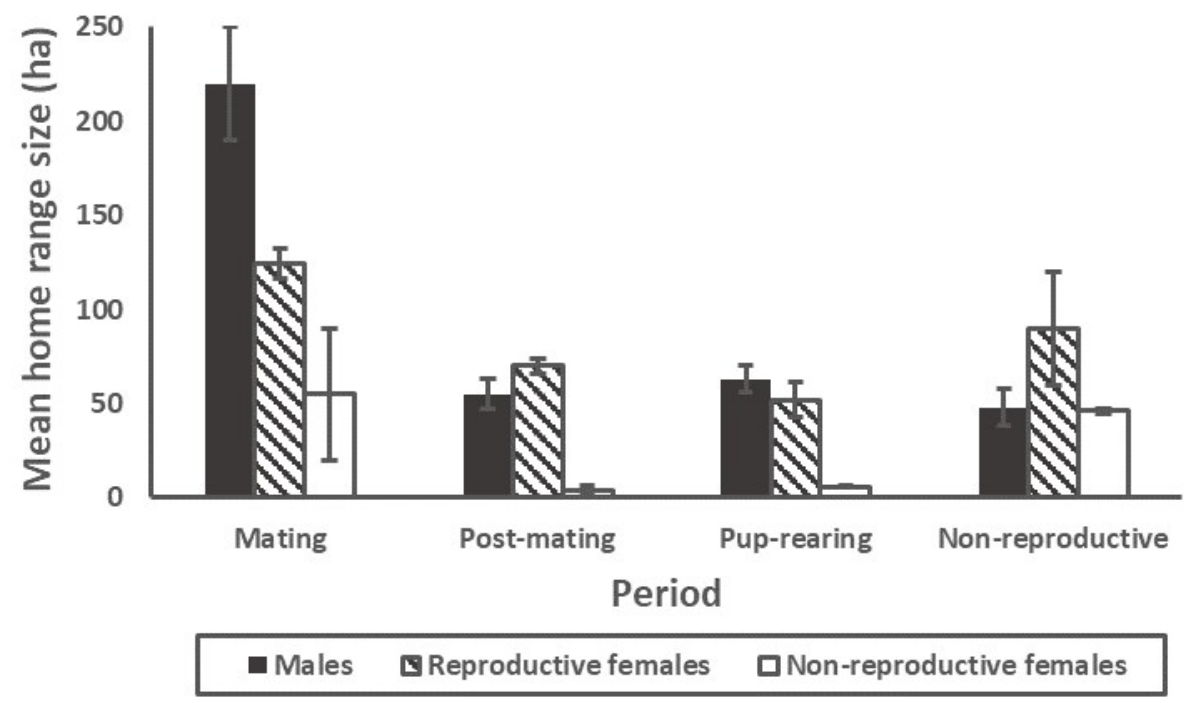

Figure 2. Island fox home range sizes (mean $\pm \mathrm{SE}$ ha based on $95 \% \mathrm{MCP})$ of adult males $(\mathrm{n}=5)$, reproductive females $(n=3)$, and non-reproductive females $(n=2)$ in each reproductive period during December 2005-July 2006, San Nicolas Island, California, USA.

Table 1. Mean percentage ( \pm SE) of overlap of $75 \%$ MCP ranges of island foxes by reproductive period for three dyad categories: (1) mate, (2) most overlapping non-mate neighbor, and (3) most overlapping same sex neighbor during December 2005-July 2006, San Nicolas Island, California, USA.

\begin{tabular}{lcccc}
\hline & $\begin{array}{c}\text { Mates } \\
(\mathrm{n}=6)\end{array}$ & $\begin{array}{c}\text { Most overlapping } \\
\text { non-mate neighbor } \\
(\mathrm{n}=8)\end{array}$ & $\begin{array}{c}\text { Most overlapping } \\
\text { same sex neighbor } \\
(\mathrm{n}=8)\end{array}$ & Average \\
\hline Mating & $75.5 \pm 10.0$ & $44.6 \pm 10.2$ & $53.9 \pm 10.9$ & $57.1 \pm 6.4$ \\
Post-Mating & $64.7 \pm 7.5$ & $33.4 \pm 11.6$ & $27.3 \pm 6.5$ & $40.6 \pm 6.1$ \\
Pupping & $70.2 \pm 7.4$ & $24.6 \pm 8.6$ & $24.1 \pm 3.1$ & $38.1 \pm 6.1$ \\
Non-Reproductive & $67.8 \pm 9.4$ & $39.0 \pm 7.4$ & $33.4 \pm 6.4$ & $45.7 \pm 5.4$ \\
Average & $69.5 \pm 2.3$ & $35.4 \pm 4.3$ & $34.7 \pm 6.7$ & \\
\hline
\end{tabular}

reproductive $\left(F_{2,16}=5.33, P=0.017\right)$ periods (Table 1$)$. Home range overlap was similar for all fox dyad categories in the mating period $\left(F_{2,16}=2.26, P=0.137\right)$.

\section{Activity}

The activity analysis was based on data from 14 foxes: 6 adult males, 5 adult females, and 3 juvenile males. There was no difference in the proportion of active locations for males and females $\left(\chi_{1}^{2}=0.24, P=0.624\right)$ with mean proportion of active locations estimated at $66.0 \pm 3.3 \%$ for males and $63.5 \pm 2.3 \%$ for females. Fox activity varied among the four daily periods $\left(F_{3,42}=94.73, P<0.001\right)$. Sunrise and afternoon activity $(39.6 \pm 2.7 \%$ and $47.9 \pm 2.7 \%$, respectively) was consistently lower than sunset and night activity (80.8 \pm $2.7 \%$ and $95.9 \pm 2.8 \%$, respectively). Activity increased from sunrise to sunset (sunrise 
vs. sunset: $t_{1,54}=6.02, P<0.001$; afternoon vs. sunset: $\left.t_{1,54}=6.79, P<0.001\right)$. The highest activity occurred at night and was significantly greater than all other time periods (sunset vs. night: $\left.t_{1,54}=4.02, P=0.001\right)$. Activity patterns did not vary with reproductive period. Mean proportion of active locations was $59.4 \pm 2.7 \%$ in the mating period, $68.6 \pm 2.8 \%$ in the post-mating period, $67.9 \pm 2.8 \%$ in the pup-rearing period, and $68.3 \pm 2.73 \%$ in the nonreproductive period. An interaction between reproductive period and daily period $\left(F_{9,124}=\right.$ $2.67, P=0.007)$ revealed that activity was lowest at sunrise in the pup-rearing period and lowest at sunset during the mating period (Fig. 3).

\section{Food Item Selection}

Vertebrate food items found in island fox scats consisted primarily of deer mice (Peromyscus maniculatus) with occasional lizards (side-blotched lizards [Uta stansburiana] or island night lizards [Xantusia riversiana]) and unidentified birds. Other food items consisted primarily of invertebrates (Jerusalem crickets [Stenopelmatus sp.], silk-spinning sand crickets [Cnemotettix sp.], ground crickets [Gryllus spp.], grasshoppers [Family Acrididae], ten-lined June beetles [Polyphylla decemlineata], June beetles [Phyllophaga spp.], darkling beetles [Eleodes spp.], beetle larvae, European earwigs [Forficula auricularia], European garden snails [Helix aspersa], sand crabs [Emerita spp.], and beach fleas [Megalorchestia californiana] and fruits (sea fig [Carpobrotus spp.], prickly pear cactus [Opuntia spp.], Australian saltbush [Atriplex semibaccata], Myoporum [Myoporum laetum], and red sand verbena [Abronia maritima]. Use of vertebrates was highest during December-January and during April-May, coinciding with mating and pup-rearing (Fig. 4).

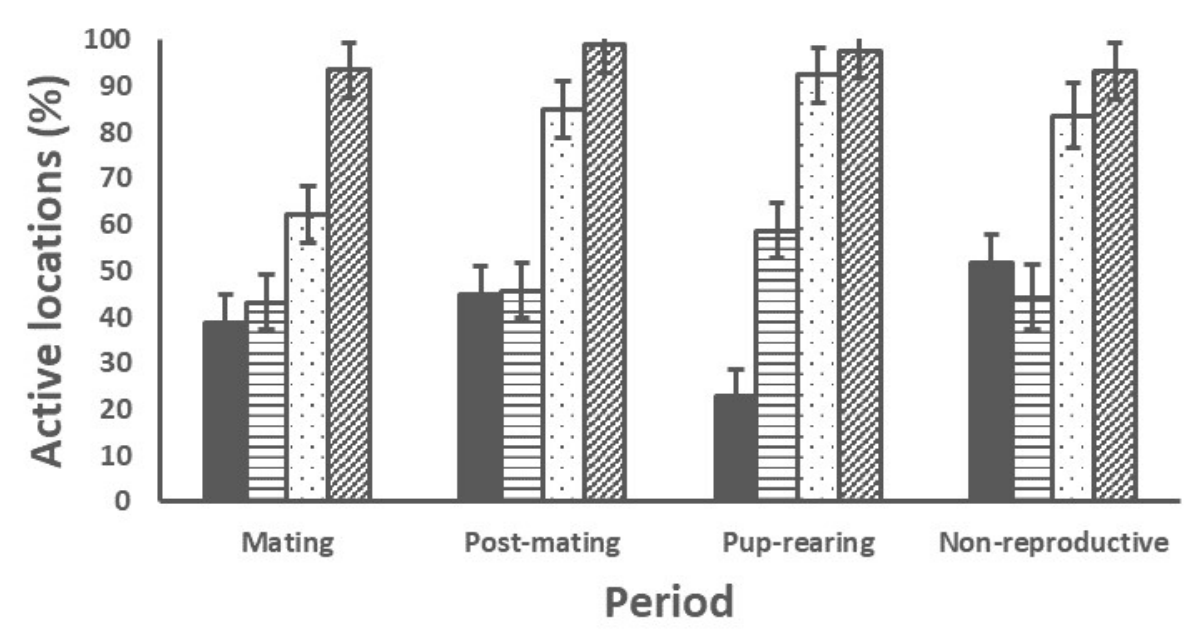

Sunrise 日Afternoon QSunset שNight

Figure 3. Mean \pm SE percent active locations of island foxes by daily period in each reproductive period during December 2005-July 2006, San Nicolas Island, California, USA. 


\section{DISCUSSION}

Variation in ecological attributes of island foxes reflected changing behavior patterns and resource use associated with reproduction. Other factors, such as seasonal variation in food resource availability, also can influence ecological attributes. However, the differences we observed among sexes and dyads suggested that social interactions relative to reproduc-

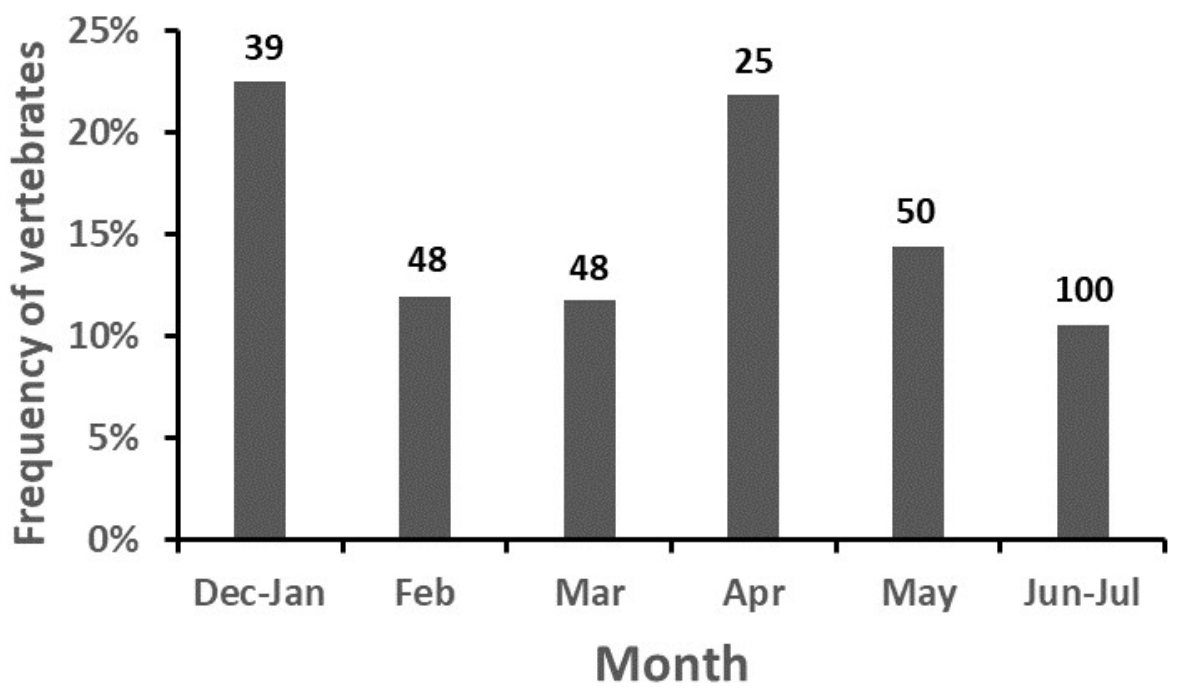

Figure 4. Frequency of occurrence of vertebrate food items in island fox scats during December 2006-July 2007, San Nicolas Island, California. Numbers above the bars are the samples sizes (scats).

tive events likely were a primary causal factor for the variation in attributes. Increased home range size during the mating period in both sexes likely can be attributed to incursions by foxes into neighboring home ranges seeking extra-pair copulations. The amount of time that mates spend together on San Miguel Island varies with the reproductive cycle, peaking during the mating season in February. Non-pair males and females interact more in January and February, the pre-mating and mating season on San Miguel Island, than in subsequent months (Ralls et al. 2013). Murdoch et al. (2008) reported that interactions between adult kit foxes from neighboring social groups, particularly non-pair males and females, increased sharply during the mating season and attributed this to extra-pair copulation attempts.

Mating with non-mates has been documented in island foxes (Roemer et al. 2001) and is common among other small canids such as arctic foxes (Alopex lagopus; Cameron et al. 2011), red foxes (Vulpes vulpes; Baker et al. 2004), swift foxes (Vulpes velox; Kitchen et al. 2006), and kit foxes (Vulpes macrotis; Murdoch et al. 2008; Ralls et al. 2001; Westall et al. 2019). Such extra-pair copulations may enhance the relative fitness of males by increasing their number of descendants. Several possible benefits to females include a reduced risk of mating with an infertile or closely related male and increased genetic diversity within litters (Clutton-Brock 2016). There are also potential costs to both sexes, such as the energetic costs of multiple matings and an increased risk of acquiring disease (Clutton-Brock 2016). 
Both Laughrin (1977) and Fausett (1993) reported that male island fox home ranges expanded in fall and winter whereas those of females did not. Similar to our results, swift fox home ranges were found to be larger during the breeding season compared with other seasons (Hines 1980; Lebsock et al. 2012). Related, nightly movement distances, particularly for males, were reported to increase during the breeding season for both kit foxes (Zoellick et al. 1989, 2002) and swift foxes (Kitchen et al. 1999). However, in one extra-pair copulation observed in kit foxes, the female was outside of her home range (Murdoch et al. 2008).

Overlap of the $95 \%$ ranges of SNI foxes was extensive. This overlap and apparent reduction in territoriality could be a function of patchy or low resource availability, high population density, or a combination of the two. Higher fox densities were correlated with smaller home ranges on San Clemente Island (Sanchez and Hudgens 2015). Extensive overlap and loss of territoriality related to low resource density also has been reported in Darwin's foxes (Pseudalopex fulvipes; Jiménez 2007) and arctic foxes (Alopex lagopus; Angerbjörn et al. 1997, Eide et al. 2004), and commonly occurs in island species as a result of limited space (Stamps and Buechner 1985, Adler and Levins 1994). The number of foxes estimated on SNI in 2006 was approximately 542 (approximately 9.3 foxes $/ \mathrm{km}^{2}$; Schmidt et al. 2007) and fox density on SNI typically is the highest among islands with foxes (Coonan et al. 2010). At high population densities, territory maintenance becomes costly because of the increased intra-specific competition (Stamps and Buechner 1985). For example, red fox home range overlap went from an average of $24 \%$ to $0 \%$ after an experimental reduction of the population density (Frey and Conover 2007).

Even the $75 \%$ ranges that more closely represent core areas overlapped considerably among SNI foxes in all periods and for all dyads. Not surprisingly, home range overlap was greatest between mates and less so between neighbors, regardless of sex. Among canids, mates share space and resources and would be expected to discourage overlap by nonmates who would compete for available resources (Kleiman 1977; Moehlman 1989; Ralls et al. 2007), and this pattern holds for island foxes (Roemer et al. 2001; Ralls et al. 2013). On Santa Cruz Island, Crooks and Van Vuren (1996) reported that home range overlaps were $>70 \%$ for mates and $<30 \%$ for non-mates, and Roemer et al. (2001) reported that mean overlap was $85 \%$ for mates and $11 \%$ for neighbors regardless of sex. These results are generally similar to the mean overlaps of approximately $70 \%$ between mates and $35 \%$ for non-mates that we observed on SNI. Significantly higher spatial overlap between mates compared with that of non-mates also has been observed among gray foxes (Chamberlain and Leopold 2000), kit foxes (Zoellick and Smith 1992; White and Ralls 1993; Zoellick et al. 2002) and swift foxes (Olson and Lindzey 2002; Schauster et al. 2002; Lebsock et al. 2012). Such overlap between mates is consistent with a monogamous mating system (Kleiman and Eisenberg 1973; Geffen and Macdonald 1992), which is the typical system among small canids (Kleiman 1977, 2011; Moehlman 1989).

The observed variation in home range overlap among reproductive periods was likely attributable to an effort by foxes to secure extra-pair copulations. Overlap was higher between mates compared with non-mates in all periods except mating. During mating, overlap increased between non-mates and did not differ from that of mates. Similarly, Lebsock et al. (2012) documented increased overlap between neighboring swift foxes during the breeding season and concluded that this overlap likely resulted from foxes attempting to secure extra-pair copulations. Zoellick and Smith (1992) concluded the same for kit foxes after not only finding a similar increase in overlap during the breeding season, but also finding males in dens with neighboring females. 
SNI foxes exhibited considerable activity during all daily periods. Most foxes exhibited activity during the sunset and night periods. Additionally, about $40 \%$ of fox locations were active during the sunrise period and almost half of fox locations were active during the afternoon period. These patterns are similar to those reported for foxes on Santa Cruz Island (Hudgens and Garcelon 2011), and considerable diurnal activity also was reported for foxes on Santa Catalina Island (Swarts et al. 2009). Observed activity patterns on SNI were generally consistent across all reproductive periods indicating that activity was not influenced by reproductive events. The relatively high diurnal activity was possibly a function of a lack of predators, particularly avian predators, which would be active during the day. Indeed, a significant shift to nocturnal activity by foxes on Santa Cruz Island was observed after golden eagles (Aquila chrysaetos) became established and began preying on foxes (Swarts et al. 2009; Hudgens and Garcelon 2011). Closely related gray foxes are considered to be primarily nocturnal but can exhibit considerable diurnal activity (Yearsley and Samuel 1980; Haroldson and Fritzell 1984). Trapp and Hallberg (1975) also reported variation in diurnal activity among gray foxes and suggested this might represent behavioral plasticity facilitating exploitation of more diurnal prey species.

Island foxes consume a diversity of food items including vertebrates, invertebrates, fruits, and anthropogenic material (Cypher et al. 2014). In winter 2005-2006, $184.2 \mathrm{~mm}$ of precipitation was recorded on SNI, which is just under the $200 \mathrm{~mm}$ annual average. Thus, no food items likely were extraordinarily abundant or rare. Food item selection by SNI foxes probably reflected seasonal item availability as well as requirements for reproduction. Use of vertebrate prey items was higher in December-January (mating period), and this likely was a function of lower invertebrate and fruit abundance during winter. Use of vertebrates also increased in April and, to a lesser extent, May. Pups were born in early-mid March. Weaning usually begins at 3-4 weeks old and this process generally lasts for 4-8 weeks (Moore and Collins 1995). Thus, pup provisioning would have occurred during April and May, coinciding with the period of increased vertebrate use we observed.

Vertebrates tend to be preferred items for provisioning pups because they are relatively large, protein-rich items that are more easily transported to pups compared with smaller items like invertebrates. Likewise, although they have diverse diets as do island foxes, kit foxes primarily provision pups with kangaroo rats (Dipodomys spp.; B. Cypher, unpublished data), and coyotes (Canis latrans) in Illinois primarily provisioned pups with white-tailed deer fawns (Odocoileus virginianus; Cypher 1993). Island fox scat samples were collected as encountered, and therefore our sample likely included scats from both reproducing and non-reproducing individuals. Use of vertebrates in April and May might have been considerably higher if samples could have been collected only from reproducing foxes that were provisioning pups.

We conclude that variation in ecological attributes among island foxes across the different seasons defined by reproductive events likely represents efforts to maximize mating opportunities, and to secure resources optimal for provisioning growing young. These patterns are consistent with those observed among other small canid species. We also acknowledge that other factors can contribute to variation in the attributes, particularly temporal and spatial variation in food resource availability. All of the foxes monitored in our study were in the same general area on SNI, so spatial variation in resources probably was not a significant factor. Temporal variation in resource availability potentially could have occurred as the island fox reproduction period on SNI coincided with the wetter winter season and the non- 
reproduction period coincided with the drier summer season. Future investigations could examine variation in ecological attributes of island foxes relative to spatial and temporal (e.g., seasonal, annual) variation in resource availability as well as reproductive events and social interactions.

\section{ACKNOWLEDGMENTS}

Financial, material, and logistical support for this project were provided by the U.S. Navy, National Geographic Society (grant \#7789-05), California State University-San Francisco, Smithsonian Institution, CSU-Stanislaus Endangered Species Recovery Program, and Tetra Tech, Inc. We thank C. Moffatt, A. Zink, G. Smith, F. Ferrara, L. Lyren, and K. Norris for technical and moral support. F. Ferrara, L. Lyren, T. McKenrick, B. Hudgens, and B. Boroski all provided helpful comments that helped improve the manuscript.

\section{LITERATURE CITED}

Adler, G. H., and R. Levins. 1994. The island syndrome in rodent populations. Quarterly Review of Biology 69:473-490.

Angerbjörn, A., J. Ströman, and D. Becker. 1997. Home range pattern in arctic foxes in Sweden. Journal of Wildlife Research 2:9-14.

Baker, P. J., S. M. Funk, M. W. Bruford, and S. Harris. 2004. Polygynandry in a red fox population: implications for the evolution of group living in canids? Behavioral Ecology 15:766-778.

California Department of Fish and Game (CDFG). 1987. Five-year status report on the island fox. Unpublished report, California Department of Fish and Game, Sacramento, CA, USA.

Cameron, C., D. Berteaux, and F. Dufresne. 2011. Spatial variation in food availability predicts extrapair paternity in the arctic fox. Behavioral Ecology 22:1364-1373.

Chamberlain, M. J., and B. D. Leopold. 2000. Spatial use patterns, seasonal habitat selection, and interactions among adult gray foxes in Mississippi. Journal of Wildlife Management 64:742-751.

Clutton-Brock, T. H. 2016. Mammal Societies. Wiley Blackwell, Chichester, West Sussex, UK.

Coonan, T., K. Ralls, B. Hudgens, B. Cypher, and C. Boser. 2013. Urocyon littoralis. The IUCN Red List of Threatened Species (Version 2014.1). Available from: http:// iucnredlist.org/details/22781/0/ (Accessed: 1 March 2019).

Coonan, T. J., C. A. Schwemm, and D. K. Garcelon. 2010. Decline and Recovery of the Island Fox: A Case Study for Population Recovery. Cambridge University Press, New York, NY, USA.

Crooks, K. R., and D. Van Vuren. 1996. Spatial organization of the island fox (Urocyon littoralis) on Santa Cruz Island, California. Journal of Mammalogy 77:801-806.

Cypher, B. L. 1993. Food item use by coyote pups at Crab Orchard National Wildlife Refuge, Illinois. Transactions of the Illinois State Academy Science 86:133-137.

Cypher, B. L., A. Y. Madrid, C. L. Van Horn Job, E. C. Kelly, S. W. R. Harrison, and T. L. Westall. 2014. Multi-population comparison of resource exploitation by island foxes: implications for conservation. Global Ecology and Conservation 2:255266. 
Eide, N. E., J. U. Jepsen, and P. Prestrud. 2004. Spatial organization of reproductive Arctic foxes Alopex lagopus: responses to changes in spatial and temporal availability of prey. Journal of Animal Ecology 73:1056-1068.

Fausett, L. L. 1993. Activity and movement of the island fox, Urocyon littoralis, on Santa Cruz Island, California. Pages 391-404 in F. G. Hocherg, editor. The Third California Islands Symposium: Recent Advances in Research on the California Islands. Santa Barbara Museum of Natural History, Santa Barbara, CA, USA.

Frey, S. N., and M. R. Conover. 2007. Influence of population reduction on predator home range size and spatial overlap. Journal of Wildlife Management 71:303-309.

Geffen, E., and D. W. Macdonald. 1992. Small size and monogamy: spatial organization of Blanford's foxes, Vulpes cana. Animal Behavior 44:1123-1130.

Gilbert, D. A., N. Lehman, S. J. Obrien, and R. K. Wayne. 1990. Genetic fingerprinting reflects population differentiation in the California Channel Island fox. Nature 344:764-767.

Gittleman, J. L., and S. D. Thompson. 1988. Energy allocation in mammalian reproduction. American Zoologist 28:863-875.

Glass, B. P. 1981. Key to the Skulls of North American Mammals. Oklahoma State University, Stillwater, OK, USA.

Goldstein, D. B., G. W. Roemer, D. A. Smith, D. E. Reich, A. Bergman, and R. K. Wayne. 1999. The use of microsatellite variation to infer population structure and demographic history in a natural model system. Genetics 151:797-801.

Haroldson, K. J., and E. K. Fritzell. 1984. Home ranges, activity, and habitat use by gray foxes in an oak-hickory forest. Journal of Wildlife Management 48:222-227.

Harris, S., W. J. Cresswell, P. G. Forde, W. J. Trewhella, T. Woolard, and S. Wray. 1990. Home-range analysis using radio-tracking data - a review of problems and techniques particularly as applied to the study of mammals. Mammal Review 20:97123.

Hines, T. D. 1980. An ecological study of Vulpes velox in Nebraska. Thesis, University of Nebraska, Lincoln, USA.

Hofman, C. A., T. C. Rick, M. T. R. Hawkins, W. C. Funk, K. Ralls K, C. L. Boser, P. W. Collins, T. Coonan, J. L. King, S. A. Morrison, S. D. Newsome, T. S. Sillett, R. C. Fleischer, and J. E. Maldonado. 2015. Mitochondrial genomes suggest rapid evolution of dwarf California Channel Islands foxes (Urocyon littoralis). PLoS ONE 10(2):e0118240.

Hofman, C. A., T. C. Rick, J. E. Maldonado, P. W. Collins, J. M. Erlandson, R. Fleischer, C. Smith, S. Sillett, K. Ralls, W. Teeter, R. Vellanoweth, and S. D. Newsome. 2016. Tracking the origins and diet of an endemic island canid (Urocyon littoralis) across 7300 years of human cultural and environmental change. Quaternary Science Reviews 146:147-160.

Hudgens, B. R., and D. K. Garcelon. 2011. Induced changes in island fox (Urocyon littoralis) activity do not mitigate the extinction threat posed by a novel predator. Oecologia 165:699-705.

Jiménez, J. E. 2007. Ecology of a coastal population of the critically endangered Darwin's fox (Pseudalopex fulvipes) on Chiloé Island, southern Chile. Journal of Zoology 271:63-77.

Junak, S. 2008. A flora of San Nicolas Island. Santa Barbara Botanic Garden, Santa Bar- 
bara, CA, USA.

Kitchen, A. M., E.M. Gese, and E. R. Schauster. 1999. Resource partitioning between coyotes and swift foxes: space, time, and diet. Canadian Journal of Zoology 77:1645-1656.

Kitchen, A. M., E. M. Gese, L. P. Waits, S. M. Karki, and E. R. Schauster. 2006. Multiple breeding strategies in the swift fox, Vulpes velox. Animal Behavior 71:1029-1038.

Kleiman, D. G. 1977. Monogamy in mammals. Quarterly Review of Biology 52:39-69.

Kleiman, D. G. 2011. Canid mating systems, social behavior, parental care, and ontogeny: are they flexible? Behavioral Genetics 41:803-809.

Kleiman, D., and J. F. Eisenberg. 1973. Comparisons of canid and felid social-systems from an evolutionary perspective. Animal Behavior 21:637-659.

Laughrin, L. L. 1977. The island fox: a field study of its behavior and ecology. Dissertation, University of California, Santa Barbara, USA.

Lebsock, A. A., C. L. Burdett, S. K. Darden, T. Dabelsteen, M. F. Antolin, and K. R. Crooks. 2012. Space use and territoriality in swift foxes (Vulpes velox) in northeastern Colorado. Canadian Journal of Zoology 90:337-344.

Moehlman, P. D. 1989. Intraspecific variation in canid social systems. Pages 143-163 in J.

L. Gittleman, editor. Carnivore Behavior, Ecology, and Evolution. Cornell University Press, Ithaca, NY, USA.

Moore, C. M., and P. W. Collins. 1995. Urocyon littoralis. Mammalian Species 489:1-7.

Moore, T. D., L. E. Spence, and C. E. Dugnolle. 1974. Identification of the dorsal hairs of some animals of Wyoming. Wyoming Game and Fish Department, Cheyenne, WY, USA.

Murdoch, J. D., K. Ralls, B. L. Cypher, and R. P. Reading. 2008. Social interactions among San Joaquin kit foxes before, during, and after mating season. Journal of Mammalogy 89:1087-1093.

Oftedal, O. T., and J. L. Gittleman. 1989. Patterns of energy output during reproduction in Carnivores. Pages 355-378 in J. L. Gittleman, editor. Carnivore Behavior, Ecology, and Evolution. Cornell University Press, Ithaca, NY, USA.

Olson, T. L., and F. G. Lindzey. 2002. Swift fox (Vulpes velox) home range dispersion patterns in southeastern Wyoming. Canadian Journal of Zoology 80:2024-2029.

Ralls, K., Cypher, B., and Spiegel, L. K. 2007. Social monogamy in kit foxes: formation, association, duration, and dissolution of mated pairs. Journal of Mammalogy 88:1439-1446.

Ralls, K., K. L. Pilgrim, P. J. White, E. E. Paxinos, M. K. Schwartz, and R. C. Fleischer. 2001. Kinship, social relationships, and den sharing in kit foxes. Journal of Mammalogy 82:858-866.

Ralls, K., J. N. Sanchez, J. Savage, T. J. Coonan, B. R. Hudgens, and B. L. Cypher. 2013. Social relationships and reproductive behavior of island foxes inferred from proximity logger data. Journal of Mammalogy 94:1185-1196.

Rick, T. C., J. J. Erlandson, R. L. Vellanoweth, T. J. Braje, P. W. Collins, D. A. Guthrie, and J. W. Stafford. 2009. The origins and antiquity of the island fox (Urocyon littoralis): AMS 14C dates from California's Channel Islands. Quarternary Research 71:93-98.

Roemer, G. W., D. A. Smith, D. K. Garcelon, and R. K. Wayne. 2001. The behavioral ecology of the island fox (Urocyon littoralis). Journal of Zoology 255:1-14. 
Roest, A. I. 1986. A Key-guide to Mammal Skulls and Lower Jaws. Mad River Press, Eureka, CA, USA.

Sanchez, J., and B. R. Hudgens. 2015. Interactions between density, home range behaviors, and contact rates in the Channel Island fox (Urocyon littoralis). Ecology and Evolution 5:2466-2477.

Schauster, E. R., E.M. Gese, and A. M. Kitchen. 2002. Population ecology of swift foxes (Vulpes velox) in southeastern Colorado. Canadian Journal of Zoology 80:307319.

Schmidt, G. A., B. R. Hudgens, and D. K. Garcelon. 2007. Island fox monitoring and demography on San Nicolas Island. 2006. Unpublished report prepared by the Institute for Wildlife Studies, Arcata, CA, USA.

Schoenherr. A. A., C. R. Feldmeth, and M. J. Emerson. 1999. Natural History of the Islands of California. University of California Press, Berkeley, CA, USA.

Stamps, J. A., and M. Buechner. 1985. The territorial defense hypothesis and the ecology of insular vertebrates. Quarterly Review of Biology 60:155-181.

Swarts, H. M., K. R. Crooks, N. Willits, R. Woodroffe. 2009. Possible contemporary evolution in an endangered species, the Santa Cruz Island fox. Animal Conservation $12: 120-127$.

Swihart, R. K., and N. A. Slade. 1985. Testing for independence of observations in animal movements. Ecology 66:1176-1184.

Trapp, G. R., and D. L. Hallberg. 1975. Ecology of the gray fox (Urocyon cinereoargenteus): a review. Pages 164-178 in M. W. Fox, editor. The Wild Canids. Van Nostrand Reinhold, New York, NY, USA.

U. S. Fish and Wildlife Service (USFWS). 2009. Final Environmental Assessment for the restoration of San Nicolas Island's seabirds and protection of other native fauna by removing feral cats. U.S. Fish and Wildlife Service, Sacramento, CA, USA.

U. S. Fish and Wildlife Service (USFWS). 2016. Endangered and threatened wildlife and plants; removing the San Miguel Island fox, Santa Rosa Island fox, and Santa Cruz Island fox from the Federal list of Endangered and Threatened Wildlife, and reclassifying the Santa Catalina Island fox from Endangered to Threatened. Federal Register 81(156):53315-53333.

U. S. Navy. 2005. Integrated natural resources management plan San Nicolas Island. U. S. Navy, Naval Base Ventura County, Point Mugu, CA, USA.

Wayne, R. K., S. B. George, D. Gilbert, P. W. Collins, S. D. Kovach, D. Girman, and N. Lehman. 1991. A morphological and genetic study of the island fox Urocyon littoralis. Evolution 45:1849-1868.

Westall, T. L., B. L. Cypher, K. Ralls, and T. Wilbert. 2019. Observations of social polygyny, communal nursing, extra-pair copulation, and inbreeding in urban San Joaquin kit foxes (Vulpes macrotis mutica). Southwestern Naturalist 63:271-276.

White, P. J., and K. Ralls. 1993. Reproduction and spacing patterns of kit foxes relative to changing prey availability. Journal of Wildlife Management 57:861-867.

Whittaker, R. J., and J. M. Fernández-Palacios. 2007. Island Biogeography: Ecology, Evolution, and Conservation. Oxford University Press, New York, NY, USA.

Wood, J. E. 1958. Age structure and productivity of a gray fox population. Journal of Mammalogy 39:74-86.

Yearsley, E. F., and D. E. Samuel. 1980. Use of reclaimed surface mines by foxes in West Virginia. Journal of Wildlife Management 44:729-734. 
Young, J. A., and C. G. Young. 1992. Seeds of Woody Plants in North America. Dioscorides Press, Portland, OR, USA.

Zar, J. H. 1984. Biostatistical Analysis. Prentice-Hall, Inc., Englewood Cliffs, NJ, USA.

Zoellick, B. W., C. E. Harris, B. T. Kelly, T. P. O’Farrell, T. T. Kato, and M. E. Koopman. 2002. Movements and home ranges of San Joaquin kit foxes relative to oil-field development. Western North American Naturalist 62:151-159.

Zoellick, B. W., and N. S. Smith. 1992. Size and spatial organization of home ranges of kit foxes in Arizona. Journal of Mammalogy 73:83-88.

Zoellick, B. W., N. S. Smith, and R. S. Henry. 1989. Habitat use and movements of desert kit foxes in western Arizona. Journal of Wildlife Management 53:955-961.

Submitted 19 September 2019

Accepted 31 December 2019

Associate Editor was A. Baker 